\title{
A Simulation Analysis of the Debt Problem in Pakistan
}

\author{
EATZAZ AHMAD and AYAZ AHMED
}

\section{INTRODUCTION}

The current debt situation in Pakistan and the resulting financial crisis require serious attempts to find a sustainable indigenous solution. As such it is essential to search ways and means to reduce dependence on external borrowing over medium to long run. ${ }^{1}$ External debt is usually created to sustain a growth rate of the economy, which is otherwise not feasible with the given state of domestic resources, technology, consumption propensity and economic management practices. However, the success of economic growth financed by external borrowing depends on two factors, namely the domestic saving rate and productivity.

A country with lower saving rate needs to borrow more to finance a given rate of economic growth. In Pakistan the flow of external loans is likely to have adversely affected the compulsion for savings. For example, no serious attempts have been made to improve tax collection or to control non-development government expenditure unless forced by the donor agencies. The adverse effect of borrowing on savings has recently been observed in [Ali et al. (1997)]. The evidence also does not support the proposition that higher rate of economic growth results in higher saving rate [see Ali et al. (1997)]. The saving rate in the private sector of Pakistan has remained low because of low real interest rates and the lack of legitimate and safe investment opportunities. Furthermore the poor and middle-income classes have been burdened with high inflation tax and no serious efforts have been made to tax the rich. Saving rate in the government sector has been deteriorating due to exponential growth in the size of this sector and extraordinarily low productivity. Government has ventured in the territories where it had no business in the first place. The current rate of savings in Pakistan is stubbornly as low as

Eatzaz Ahmad and Ayaz Ahmed are respectively Associate Professor at the Quaid-i-Azam University, Islamabad and Staff Economist at the Pakistan Institute of Development Economics, Islamabad.

Authors' Note: We wish to thank Professor Syed Nawab Haider Naqvi for his encouragement and useful comments on the paper.

${ }^{1}$ Using Neo-classical growth framework, Ahmad and Paul (1994) and Crouch (1973) have shown that the benefits of foreign investment can only be temporary unless it increases national savings rate and/or productivity. 
it was many years ago. Thus the failure to increase the national saving rate alone explains why the need for external borrowing has continued to rise over the years in Pakistan.

A decline in productivity is something extra-ordinary because all the on-going innovations in technology are meant to improve productivity. New technologies that are inferior to the existing technologies quickly disappear from the scene. Nevertheless a recent study by Ahmad and Idress (1998) shows that total factor productivity in the manufacturing sector has declined by about one percent over the period 1971-91. This loss in productivity can most plausibly be explained by inefficiency in the economy, especially in the public sector.

In the light of above background this study aims to suggest a policy prescription that can provide a sustainable solution to the present debt crises. The analysis is based on a three-gap model of resource flows. The model is stock-flow consistent as it considers both the current and capital accounts of the transactions taking place across the private and public sectors and the rest of the world.

A similar model has recently been used in Ahmad (1997) to study the effects of various fiscal measures on the debt position and in Ahmad (1996) to discuss the role of foreign capital inflows in reducing the size of debt. The present study considers a broader policy prescription that includes both the fiscal and monetary instruments. ${ }^{2}$

The paper is planned as follows. Section 2 provides a historic overview of the resource deficiency in Pakistan. A three-gap simulation model is presented in Section 3. Section 4 provides statistical simulations for various indicators of resource deficiency over the next two decades and studies the effectiveness of a policy prescription in addressing the problem.

\section{TRENDS IN RESOURCE DEFICIT, BORROWING, AND DEBT}

When Pakistan resorted to external borrowing in 1950s and 1960s, the objective was to accelerate growth rate of the economy. Since the domestic saving rate was too low to finance economic growth through productive investment, Pakistan opted for external borrowing. The idea was that the increased growth rate in future would raise the saving rate and produce sufficient exportable surplus to retire the debt. However, presently we need to borrow in order to avoid debt default and improve our credit rating so that we can maintain the supply line of borrowing. The danger is that if the supply lines are cut-off, Pakistan's economy will collapse.

At least in one respect the growth strategy of 1960s was successful in the sense that resources generated through external borrowings resulted in high rate of economic growth. If the same pace of growth were sustained, the adverse trend in debt accumulation might have reversed at some stage. The situation in 1970s was still

${ }^{2}$ All the earlier studies on debt simulation in Pakistan are based on two gap models. See, for example, Burney (1988); Chaudhary (1988); Naqvi (1970) and Rahman (1967) 
manageable despite a reduction in growth rate of the economy, mainly because the size of external debt was small and the terms and conditions for external borrowing were favourable. In 1980s the American aid to assist in the Afghan war helped postpone the crisis. During this period, however, the composition of external debt changed gradually from long term debt to short term debt with higher rates of interest.

By the time American aid was dried up, Pakistan had accumulated sufficient amount of external debt to worry about. The successive governments not only opted to postpone the burden by rolling-over the existing debt but also magnified the problem by indulging in unrealistic adventures and ignoring the core issue of management. As a result most of the efforts of economic policy makers and civil servants have been diverted to negotiating bigger and bigger loan agreements with the donors, and trying to meet the targets imposed by the donor agencies. Not only did we fail to design a sustainable development strategy, but we also managed to waste the highly specialised human resource on misdirected objectives.

In the past two decades or so the debt position has worsened very rapidly. This is evident from the trends in various indicators as shown in Table 1. The table shows that the primary budget deficit has increased by almost 13 percent per annum over the period 1980-81 to 1996-97. Thus even if debt servicing is ignored, the government's budget position has deteriorated over the years. The surplus in the private sector has also worsened quite significantly to the extent that in the recent years it has almost vanished. While primary budget deficit has grown due to expansion in the size of public sector, the observed deterioration in the private sector's surplus can be attributed to rising consumption propensity and over-invoicing of investment expenditure to camouflage consumption loans. The table also shows that primary budget deficit has outweighed the private sector's primary surplus, with the result that the primary external deficit has been positive and growing at the rate of more than 14 percent per annum.

The interest and principal payments on public debt and rental payments on private foreign capital have been increasing even at faster rates. The extra-ordinary growth in debt servicing payments is mainly due to the rising public debt and inflow of capital, and partially due to the rising rates of interest on external as well as internal debt and the amortisation rate of external debt. With increasing difficulty in arranging longterm soft external loans, which have also lead to declining credit worthiness of Pakistan, the composition of external debt has drifted towards short term commercial loans. This in turn has resulted in the rising interest and amortisation rates and shortening of the amortisation period as is evident from the table. Likewise the interest rate on internal borrowing has to be increased in order to compete in the domestic loanable funds market. 
Table 1

Indicators of Resource Deficiency (Billion Rupees Per Year)

\begin{tabular}{lccccc}
\hline Indicators of Resource Deficits & $1980-85$ & $1985-89$ & $1989-93$ & $1993-97$ & Growth Rate \\
\hline Primary Budget Deficit & 12.85 & 35.82 & 45.42 & 55.72 & 12.79 \\
Primary Private Sector Deficit & -3.68 & -24.46 & -20.08 & -9.09 & \\
Primary External Deficit & 9.17 & 11.35 & 25.34 & 46.64 & 14.44 \\
Interest Payments on External Debt & 2.97 & 6.83 & 13.51 & 24.70 & 17.09 \\
Rental Payments on Foreign Capital & 1.95 & 6.58 & 15.76 & 38.52 & 27.40 \\
Principal Payments on External Debt & 5.02 & 11.87 & 20.56 & 44.23 & 17.50 \\
External Debt Servicing & 7.99 & 18.70 & 34.07 & 68.93 & 17.34 \\
Debt Servicing and Rental Payments Abroad & 9.94 & 25.28 & 49.83 & 107.45 & 19.36 \\
Interest Payments on Internal Debt & 7.86 & 22.00 & 48.47 & 97.57 & 21.23 \\
Total Debt Servicing & 15.85 & 40.71 & 82.54 & 166.50 & 19.35 \\
Current External Deficit & 14.09 & 24.77 & 54.60 & 109.86 & 17.18 \\
Current Budget Deficit & 23.69 & 64.65 & 107.41 & 177.99 & 16.96 \\
Net Internal Borrowing & 21.62 & 41.16 & 70.52 & 108.38 & 12.25 \\
Net External Borrowing & 13.11 & 31.30 & 55.43 & 102.03 & 20.82 \\
Gross External Borrowing & 18.13 & 43.18 & 75.99 & 146.26 & 18.77 \\
External Debt & 112.70 & 221.44 & 399.07 & 736.39 & 15.04 \\
Internal Debt & 105.50 & 268.73 & 494.07 & 871.54 & 17.44 \\
Interest Rate on Internal Debt & 9.00 & 9.52 & 11.35 & 12.76 & 3.39 \\
Interest Rate on External Debt & 2.97 & 3.57 & 3.93 & 3.91 & 2.35 \\
Amortisation Rate of External Debt & 4.90 & 6.30 & 5.96 & 6.91 & 2.75 \\
External Debt Servicing Rate & 7.88 & 9.88 & 9.89 & 10.81 & 2.59 \\
Average Amortisation Period of Outstanding Debt & 27.41 & 24.92 & 22.33 & 22.95 & -1.60 \\
Foreign Exchange Reserves & 16.18 & 12.88 & 19.18 & 77.09 & 11.13 \\
Foreign Equity Investment & 3.11 & 4.69 & 7.64 & 27.89 & 14.83 \\
Foreign Direct Investment & 0.86 & 2.76 & 8.89 & 37.13 & 29.45 \\
Total Foreign Investment & 3.97 & 7.46 & 16.53 & 65.02 & 21.29 \\
\hline & & & & & \\
\hline
\end{tabular}

It is also evident from the table that the current account external deficit has been rising quite fast due to the rising primary external deficit and, especially the rising interest payments on external debt and rental payments on foreign capital. Likewise the current account budget deficit has been rising almost at the same rate due to the rising primary budget deficit and interest payments on external and internal debts.

The statistics in Table 1 also show that foreign capital inflow both in terms of equity and direct foreign investment has increased quite significantly, especially during 1990s. Although the direct effect of capital inflows is that it helps control the need for external borrowing, yet the resulting increase in rental payments abroad adds to the burden on current account external balance and thereby indirectly increases the need for external borrowing. 
Table 2 shows the trends in deficits, borrowings and debts as ratios to the nominal GDP. Since all the measures of resource deficit are also given in nominal terms, the inflationary factor is eliminated from these ratios. A rising (declining) ratio would indicate that the resource deficit is growing in real sense faster (slower) than the real GDP. We observe that, while the primary budget and external deficits as proportions to the GDP have been more or less stable, the debt servicing and rental payments, and the current account deficits have been rising faster that the nominal GDP. That is, the burden of debt servicing and current account balances have deteriorated in real terms as well. The same is the case with net and gross external borrowing and external and internal debt. On the other hand net internal borrowing has not increased as fast as the nominal GDP.

Table 2

Indicators of Resource Deficiency (Percentage of the GDP)

\begin{tabular}{lccccc}
\hline Indicators of Resource Deficits & $1980-85$ & $1985-89$ & $1989-93$ & $1993-97$ & Growth Rate \\
\hline Primary Budget Deficit & 3.35 & 5.48 & 4.17 & 2.80 & -0.73 \\
Primary Private Sector Deficit & -0.91 & -3.78 & -1.94 & -0.63 & \\
Primary External Deficit & 2.45 & 1.70 & 2.24 & 2.16 & 0.90 \\
Interest Payments on External Debt & 0.79 & 1.07 & 1.22 & 1.24 & 3.58 \\
Rental Payments on Foreign Capital & 0.48 & 1.04 & 1.40 & 1.89 & 13.95 \\
Principal Payments on External Debt & 1.31 & 1.89 & 1.85 & 2.18 & 4.00 \\
External Debt Servicing & 2.11 & 2.97 & 3.07 & 3.42 & 3.83 \\
Debt Servicing and Rental Payments Abroad & 2.59 & 4.00 & 4.47 & 5.31 & 5.84 \\
Interest Payments on Internal Debt & 2.01 & 3.41 & 4.34 & 4.86 & 7.71 \\
Total Debt Servicing & 4.12 & 6.37 & 7.41 & 8.28 & 5.84 \\
Current External Deficit & 3.72 & 3.81 & 4.85 & 5.29 & 3.66 \\
Current Budget Deficit & 6.16 & 9.96 & 9.74 & 8.89 & 3.45 \\
Net Internal Borrowing & 5.29 & 6.60 & 6.32 & 5.44 & -1.33 \\
Net External Borrowing & 3.33 & 4.98 & 4.98 & 5.17 & 7.33 \\
Gross External Borrowing & 4.64 & 6.87 & 6.83 & 7.36 & 5.25 \\
External Debt & 30.16 & 35.00 & 36.07 & 36.82 & 1.53 \\
Internal Debt & 27.50 & 42.28 & 44.55 & 43.54 & 3.92 \\
Foreign Exchange Reserves & 4.40 & 2.15 & 1.76 & 4.00 & -2.38 \\
Foreign Equity Investment & 0.88 & 0.81 & 0.66 & 1.45 & 0.97 \\
Foreign Direct Investment & 0.23 & 0.44 & 0.77 & 1.84 & 15.94 \\
Total Foreign Investment & 1.11 & 1.25 & 1.43 & 3.29 & 7.76 \\
\hline & & & & & \\
& & & &
\end{tabular}


Another notable observation is that contrary to the generally held perception, during 1990s the current account as well as primary budget deficits have shown some improvement in relation to the GDP growth, while the primary and current account external deficits have been relatively stable. This could partially be due to the discipline imposed by the so-called IMF conditionalities. Nevertheless it is evident from the above observations that the resource deficiency and debt positions have severely worsened in Pakistan during 1980s and 1990s.

\section{THE MODEL}

The full three-gap model has been derived in Ahmad (1997). In this paper we consider a variation of the model to highlight the role of monetary money supply, inflation and exchange rate. However, to avoid repetition, we give only a brief description of the model. Unless otherwise stated, all variables are measured in domestic currency at current prices. The parameters relate either to real quantities (at constant prices) or to nominal values in foreign currency.

The following notations are used in the paper:

$$
\begin{aligned}
a_{i}^{E D} & =\text { Amortisation rate of external debt. } \\
B M_{i} & =\text { Base money. } \\
C_{i}^{G} & =\text { Government consumption expenditure. } \\
C_{i}^{P} & =\text { Private consumption expenditure. } \\
C B D_{i} & =\text { Current account budget deficit. } \\
C E D_{i} & =\text { Current account external deficit. } \\
e_{i} & =\text { Rate of exchange rate depreciation. } \\
E D_{i} & =\text { External debt. } \\
F D I_{i} & =\text { Private foreign direct investment. } \\
F D K_{i} & =\text { Stock of private foreign direct capital. } \\
F E I_{i} & =\text { Private foreign equity investment. } \\
F E K_{i} & =\text { Stock of private foreign equity capital. } \\
F E R_{i} & =\text { Foreign exchange reserves. } \\
G_{i}^{F D K} & =\text { Growth rate of foreign direct capital in real terms. } \\
G_{i}^{F E K} & =\text { Growth rate of foreign equity capital in real terms. } \\
G_{i}^{F E R} & =\text { Growth rate of foreign exchange reserves in real terms. } \\
G_{i}^{B M} & =\text { Growth rate of base money. }
\end{aligned}
$$




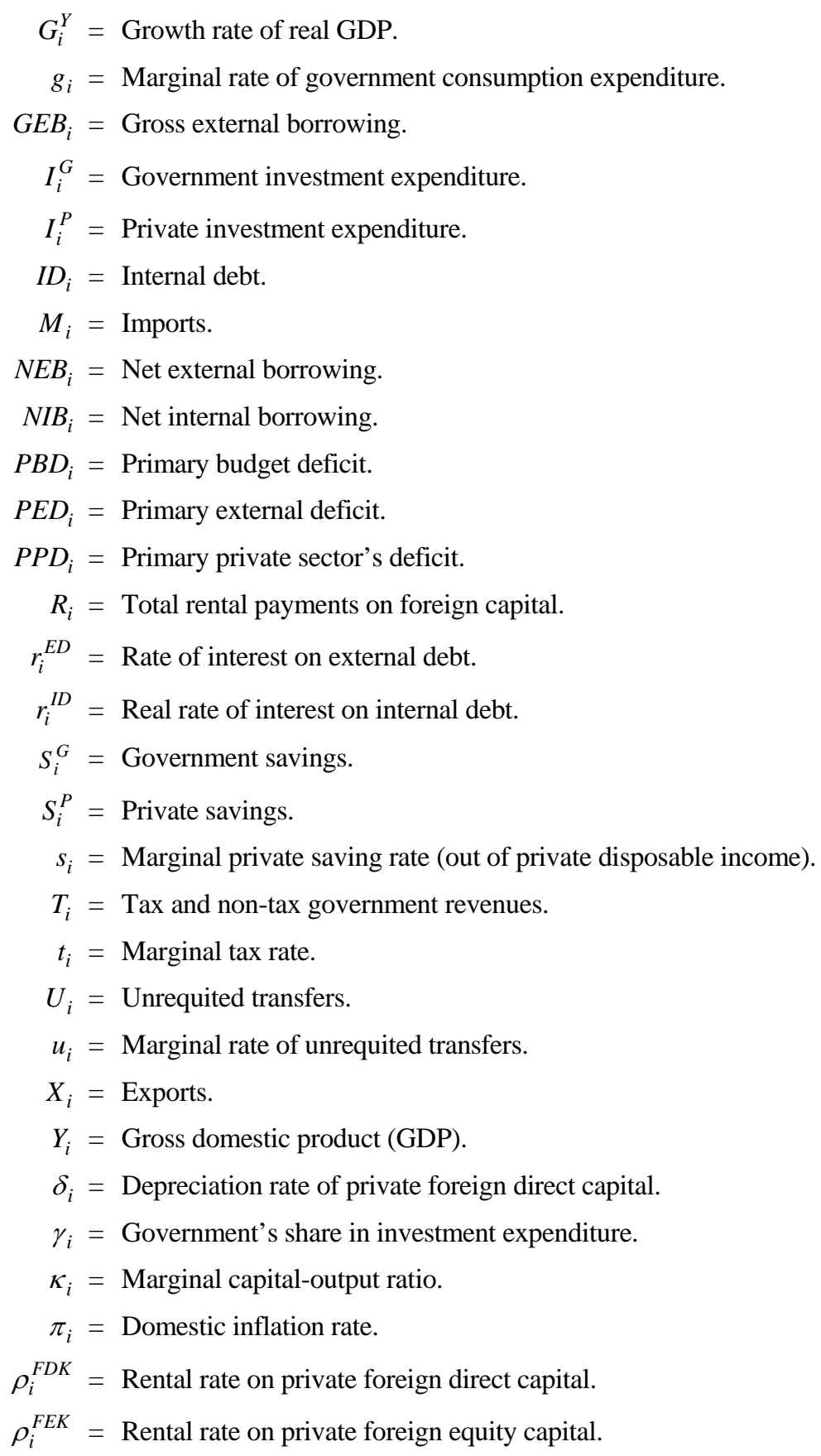


According to three-gap model external deficit is a mirror image of the domestic resource deficit, where the latter is split into its private and public counterparts. We can define the primary external, budget and private sector deficits and their interrelationship as follows.

$$
\begin{aligned}
& P E D_{i}=\left(C_{i}^{G}+C_{i}^{P}+I_{i}^{G}+I_{i}^{P}\right)-\left(Y_{i}-U_{i}\right)=M_{i}-X_{i}-U_{i}, \quad \ldots \quad \ldots \\
& \begin{array}{llllll}
P B D_{i}=C_{i}^{G}+I_{i}^{G}-T=I_{i}^{G}-S_{i}^{G}, & \ldots & \ldots & \ldots & \ldots
\end{array} \\
& P P D_{i}=C_{i}^{P}+I_{i}^{P}+T_{i}-Y_{i}-U_{i}=I_{i}^{P}-S_{i}^{P}, \quad \ldots \quad \ldots \quad \ldots \quad \ldots \\
& \begin{array}{llllllll}
P E D & =P G D_{i}+P P D_{i}, & \ldots & \ldots & \ldots & \ldots & \ldots & \ldots
\end{array}
\end{aligned}
$$

It can be shown that the time paths of the primary resource deficits are given by the following equations. The proof is available from the authors.

$$
\begin{aligned}
& P P D_{i}=\left(1+\pi_{i}\right)\left[P P D_{i-1}+\left\{\begin{array}{r}
\gamma_{i} \kappa_{i} G_{i+1}^{Y}\left(1+G_{i}^{Y}\right)-\gamma_{i-1} \kappa_{i-1} G_{i}^{Y} \\
-\left(t_{i}-g_{i}\right) G_{i}^{Y}
\end{array}\right\} Y_{i-1}\right] \quad \ldots \\
& P B D_{i}=\left(1+\pi_{i}\right)\left[P B D_{i-1}+\left\{\begin{array}{r}
\left(1-\gamma_{i}\right) \kappa_{i} G_{i+1}^{Y}\left(1+G_{i}^{Y}\right)-\left(1-\gamma_{i-1}\right) \\
\kappa_{i-1} G_{i}^{Y}-s_{i}\left(1+u_{i}-t_{i}\right) G_{i}^{Y}
\end{array}\right\} Y_{i-1}\right] \ldots \\
& P E D_{i}=\left(1+\pi_{i}\right)\left[P E D_{i-1}+\left\{\begin{array}{l}
\kappa_{i} G_{i+1}^{Y}\left(1+G_{i}^{Y}\right)-\kappa_{i-1} G_{i}^{Y} \\
-\left(\left(t_{i}-g_{i}\right)+s_{i}\left(1+u_{i}-t_{i}\right)\right) G_{i}^{Y}
\end{array}\right\} Y_{i-1}\right] \ldots \quad \ldots
\end{aligned}
$$

In order to proceed further we need to trace the relationship between stock and flow components of various variables. Since the primary resource deficits are measured in domestic currency, the interest payments on external debt and the rental payments on private foreign capital must also be denominated in domestic currency for aggregation purposes. We assume that interest rate on internal debt and the rental rate on foreign equity capital are subject to full Fisher effects. ${ }^{3}$ Therefore the two are adjusted one to one for inflation. However, we assume that foreign direct capital is fully indexed for inflation and, therefore, the rental rate on foreign direct capital does not incorporate

${ }^{3}$ According to the Fisher effect, under perfect foresight, with flexible prices and in the absence of any unexpected shocks, nominal interest rate fully adjusts to the expected inflation rate to yield a constant real rate of interest. Likewise, if the foreign inflation rate is constant, the nominal exchange rate will also adjust with changes in the domestic inflation to yield a constant real exchange rate [see Tanzi et al. (1988)]. Although the validity of Fisher effects is an empirical question, there is no way one could predict the future course of disparity from the neutral assumption made above. 
inflationary factor. Finally, assuming that the purchasing power parity holds, the exchange rate depreciation factor is equal to the ratio of domestic inflation factor to foreign inflation factor. This means that external debt is also indexed for domestic inflation. It also follows that the interest rate on external debt does not include inflationary factor.

Under the above assumptions we can write

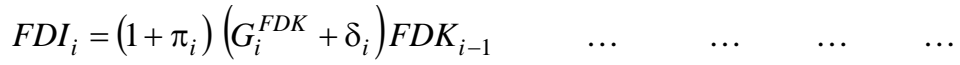

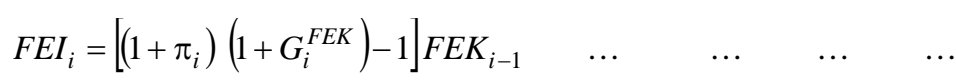

$$
\begin{aligned}
& \triangle F E R_{i}=\left[\left(1+\pi_{i}\right)\left(1+G_{i}^{F E R}\right)-\left(1+e_{i}\right) \mid F E R_{i-1} \quad \ldots \quad \ldots \quad \ldots\right. \\
& \begin{array}{llllllll}
\Delta B M_{i}=G_{i}^{B M} B M_{i-1} & \ldots & \ldots & \ldots & \ldots & \ldots & \ldots
\end{array}
\end{aligned}
$$

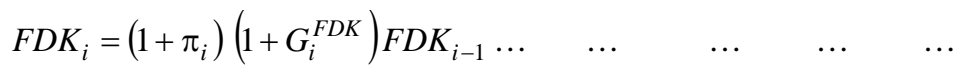

$$
\begin{aligned}
& \begin{array}{lllllll}
\text {FEK}_{i} & =\left(1+\pi_{i}\right)\left(1+G_{i}^{\text {FEK }}\right) F E K_{i-1} & \ldots & \ldots & \ldots & \ldots & \ldots
\end{array}
\end{aligned}
$$

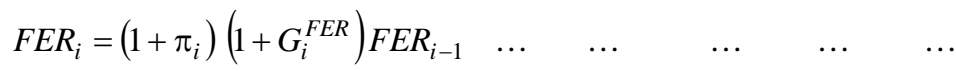

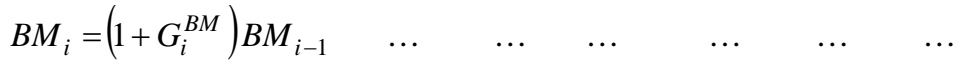

The time paths of current account external and budget deficits are as follows.

$$
\begin{aligned}
C E D_{i}= & P E D_{i}+\left(1+e_{i}\right) r_{i}^{E D} E D_{i-1}+\left(1+\pi_{i}\right) \rho_{i}^{F D K} F D K_{i-1} \\
& +\left[\left(1+\pi_{i}\right)\left(1+\rho_{i}^{F E K}\right)-1\right] F E K_{i-1} \\
C B D_{i}= & P B D_{i}+\left(1+e_{i}\right) r_{i}^{E D} E D_{i-1}+\left[\left(1+\pi_{i}\right)\left(1+r_{i}^{I D}\right)-1\right] I D_{i-1} \quad \ldots \quad \ldots
\end{aligned}
$$

Net external borrowing is required to finance the part of current account deficit which is not covered by private capital inflow, and to increase foreign exchange reserves [see Cohen (1988)], while gross external borrowing is equal to the net borrowing plus principal payments. That is,

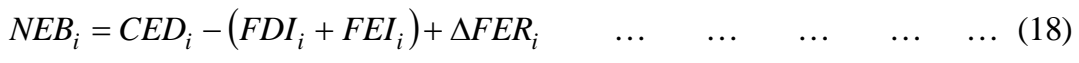

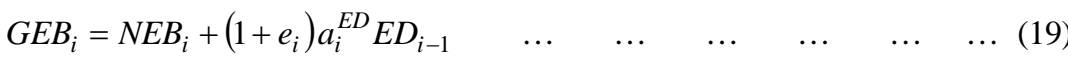


Budget deficit is financed by three sources: internal borrowing, external borrowing net of the increase in foreign exchange reserves, and monetary borrowing or the change in base money. Therefore the net internal borrowing can be written as

$$
N I B_{i}=C B D_{i}-\left(N E B_{i}-\triangle F E R_{i}\right)-\triangle B M_{i} \quad \ldots \quad \ldots \quad \ldots \quad \ldots
$$

Finally, external debt, measured in local currency, accumulates for two reasons: the local currency value of the existing volume of external debt increases due to exchange rate depreciation; and/or if the net external borrowing is positive during the current period. The internal debt, on the other hand, accumulates only on account of net internal borrowing. Therefore,

$$
\begin{array}{llllllll}
E D_{i}=\left(1+e_{i}\right) E D_{i-1}+N E B_{i} & \ldots & \ldots & \ldots & \ldots & \ldots & \ldots & (21) \\
I D_{i}=I D_{i-1}+N I B_{i} & \ldots & \ldots & \ldots & \ldots & \ldots & \ldots & (22)
\end{array}
$$

This completes the structure of our model, which can now be used to simulate the time paths of net external and internal borrowings and debts under alternative parametric assumptions.

\section{PARAMETER ESTIMATES AND NUMERICAL SIMULATIONS}

We shall now use Equations 5-22 to study the time path of some of the key indicators of resource deficiency in Pakistan. The base period for projections is chosen to be 1996-97 which was relatively a normal year and for which all the required data are available in the final form. The time paths are derived for the period 1997-98 to 201920. With a few exceptions various parameters required for simulation are estimated using compound growth rates, averages, etc. over the past 10 years. Since no separate information is available on the rental payments on the foreign direct and equity capital, the rental rates are estimated as parameters from the following non-linear regressing equation using the past 20 years data. ${ }^{4}$

$$
R_{i}=\left(1+\pi_{i}\right) \rho^{F D K} F D K_{i-1}+\left[\left(1+\pi_{i}\right)\left(1+\rho^{F E K}\right)^{-1}-1\right] F E K_{i-1} \quad \ldots \quad \ldots
$$

The series of foreign direct and equity capital stocks are estimated by accumulating past investments for the period 1959-60 and applying 5 percent depreciation rate on the foreign direct capital.

${ }^{4}$ No serious econometric problems such as autocorrelation or multicollinearity are apparent from the results and the estimates of both the parameters $\rho^{F D K}$ and $\rho^{F E K}$ given in Table 3 are statistically significant. 
All the required data are taken from 50 Years of Statistics in Pakistan, various issues of Economic Survey and Statistical Supplements (Finance Division, Government of Pakistan) and Annual Report (State Bank of Pakistan). The estimated parameters are given in Table 3.

Table 3

Estimates of the Parameters

\begin{tabular}{lc}
\hline Parameter & Estimate \\
\hline$a_{i}^{E D}=$ amortisation rate of external debt & 0.06 \\
$e_{i}=$ rate of exchange rate depreciation & 0.09 \\
$G_{i}^{Y}=$ growth rate of real GDP & 0.05 \\
$G_{i}^{F E R}=$ growth rate of the foreign exchange reserves & 0.05 \\
$G_{i}^{F E K}=$ growth rate of foreign equity capital & 0.1 \\
$G_{i}^{F D K}=$ growth rate of foreign direct capital & 0.13 \\
$G_{i}^{B M}=$ growth rate of base money & 0.13 \\
$g_{i}=$ marginal rate of government consumption expenditure & 0.13 \\
$r_{i}^{E D}=$ dollar rate of interest on external debt & 0.04 \\
$r_{i}^{I D}=$ real rate of interest on internal debt & 0.02 \\
$s_{i}=$ marginal private saving rate (out of private disposable income) & 0.12 \\
$t_{i}=$ marginal tax rate & 0.17 \\
$u_{i}=$ marginal rate of unrequited transfers & 0.04 \\
$\delta_{i}=$ depreciation rate of private foreign direct capital & 0.05 \\
$\gamma_{i}=$ government's share in investment expenditure & 0.48 \\
$\kappa_{i}=$ marginal capital-output ratio & 4 \\
$\pi_{i}=$ inflation rate & 0.1 \\
$\rho_{i}^{F D K}=$ rental rate on private foreign direct capital & 0.11 \\
$\rho_{i}^{F E K}=$ rental rate on private foreign equity capital & 0.07 \\
\hline &
\end{tabular}


The expected levels of primary deficits, current external and budget deficits, the net and gross external borrowings, net internal borrowing and external and internal debt for the period 1997-98 to 2019-20 are reported in Table 4. These results show that the primary budget deficit is expected to rise by about 19 percent annually. The primary private sector's deficit, on the other hand, would grow at a lower rate, 9 percent per annum. Since, however, the private sector's deficit would remain quite low as compared to the budget deficit, its slow growth would have negligible effect on the primary external deficit, which is expected to grow at the rate of 18 percent per annum.

The current account external deficit is expected to grow at the rate of 20 percent per annum, faster than the growth in the budget deficit (about 17 percent per annum). Since the current account external deficit is the sum of the budget deficit and the private sector's deficit, this pattern indicates deterioration in the private sector's current account balance as well. The main reason for this deterioration and, hence a faster growth in current account external deficit as compared to the current account budget deficit, is the expected growth in rental payments on private foreign capital.

If, however, the private foreign capital inflow continues to grow at the present rate, it will more than offset the shortfall in the private sector's balance. This also means that net external borrowing will remain substantially below the current account external deficit, so that the government will rely heavily on internal borrowing to cover the budget deficit. Thus net internal borrowing would grow at a faster rate (about 18 percent per annum) than the net external borrowing (about 16 percent per annum). On the other hand external debt is expected to grow faster than the internal debt because external debt is indexed for exchange rate depreciation, and hence for inflation as it is contracted in foreign currency, while the internal debt is not indexed for inflation.

The above simulation results include the effects of inflation. In order to remove the inflationary factor and to place the results in relation to real growth in the growing economy, we now divide all the variables by the nominal GDP. Table 5 provides the relevant information.

The table shows that the primary budget and external deficits as percentages of the GDP are expected to grow by more than 2 percent per annum. This means that in real terms the two measures of deficits are expected to grow faster than real GDP. The primary deficit in the private sector, on the other hand, would grow in real terms much slower than the growth rate of real GDP

Although the current account external deficit, as a percentage of the GDP, is expected to grow at about of 4 percent per annum, the net external borrowing will remain fairly stable around 4 percent of GDP. The basis for this expectation is the assumption that private capital inflow will continue to contribute favourably to the capital account of the balance of payments. The current account budget deficit as a percentage of the GDP is also expected to remain fairly stable while the net internal borrowing would rise at around 2 percent per annum. These trends, in turn, translate into an 
Table 4 
Table 5 
exponentially rising time path for the external debt and a relatively stable U-shaped time path of internal debt.

The above results show that Pakistan's external debt position is expected to become worse in future while the position of internal debt will not improve. The burden of external debt servicing will rise to more than 8 percent of GDP and the current account external and budget deficits will rise beyond the acceptable limits.

We can now study the effects of changes in parameters of the system on the simulated time paths of resource deficits. Using a model similar to the one presented here, Ahmad (1997) has performed such simulation exercises and has suggested two mixed policies to reduce the debt burden. These policies are mainly focussed on fiscal measures such as changes in tax rate, government consumption rate and the share of public sector in investment expenditure. Although the present study is based on updated estimates of the parameters, there is not much point in repeating the entire simulation exercise, which in any case is illustrative only. In this paper we shall consider a broader policy mix that also includes monetary policy to control inflation and thereby the rate of exchange rate devaluation.

The policy mix is designed with the multiple objectives of reducing the debt burden, maintaining a high and steady growth rate of GDP, producing stability in the economy and minimising the financial risk due to low foreign exchange reserves. After a number of experiments we have come up with the following policy mix that has a balanced effect on all accounts.

(a) The tax rate is increased by 1 percent in each year starting from the year 1998-99 till it is increased from 17 percent to 20 percent in the year 2000-01.

(b) The rate of government consumption expenditure is reduced by 1 percent starting from 1998-99 till it settles at 10 percent in the 2000-01.

(c) The share of public sector in investment expenditure is reduced by 2 percent in each year starting from 1999-00 till it is reduced from the present 48 percent to 40 percent in 2002-03.

(d) GDP growth rate is increased from the present 5 percent per annum to 6 percent per annum gradually over a period of 10 years from 2000-01 to 2009-10.

(e) The annual growth rate of foreign exchange reserves is set at 20 percent for 1998-99 to 2003-04 till the foreign exchange reserves reach at about 5 percent of GDP. From the year 2004-05 onwards the growth rate is set equal to the target GDP growth rate of 6 percent so that the foreign exchange reserves remain around 5 percent of GDP in the subsequent years.

(f) The growth rate of money supply is reduced from the current 13 percent by 1 percent per annum over the period 1999-00 to 2005-06 when it reaches to 6 percent. Assuming full Fisher effects, it is expected that inflation rate and the 
rate of exchange rate depreciation will decline by the same magnitudes and settle at 3 percent and 2 percent respectively with a lag of one year.

(g) With the resulting stability in price level and exchange rate, a better budget position and the declining role of public sector, it is expected that real interest rates on domestic saving instruments will rise and the private sector will gain confidence. These factors along with other policy measures are expected to raise the private saving rate by 1 percent per annum over the period 1999-00 to 2001-02 till it reaches to 15 percent.

(h) Finally, we assume that with more stability and the expanding private sector, productivity will rise and as a result capital-output ratio will decline gradually to 3.5 over the period 1999-00 to 2003-04.

Although the space does not allow a separate treatment of each of the above policy measure, we can nevertheless discuss briefly the qualitative implications of each. The increase in tax rate produces favourable effects on all accounts; but the decrease in external deficit is smaller than the decrease in budget deficit because the resulting decrease in the overall resource deficiency, which determines the size of the external deficit, is partially offset by reduced private savings. Despite this, however, the favourable effects on external borrowing and external debt would be greater than the effects on internal borrowing and internal debt. The reason is that the government would reduce internal borrowing only to the extent that the reduction in the budget deficit is not fully matched by the reduction in external borrowing.

A cut in government consumption expenditure leaves the private sector's resource balance unchanged. Therefore the reduction in the primary external deficit must be equal to the reduction in primary budget deficit. It also follows that the reduction in current account budget deficit would be equal to the reduction in current account external deficit, and to the reduction in net external borrowing, with the net internal borrowing remaining unchanged.

The share of public sector in investment expenditure is reduced gradually keeping in view the political difficulties attached with privatisation. Since a decrease in the government's share in investment implies an equal increase in the private sector's share, the overall investment and resource deficiency in the country remains unaffected. Therefore, the external balance remains unchanged. ${ }^{5}$ With the investment in public sector decreasing, the budget deficit improves. Furthermore, government must fully crowd out in terms of reduced borrowing from the domestic capital market in order to make room for the private-sector investment. Thus both net internal borrowing and internal debt would decrease.

${ }^{5}$ These results rest on the assumption that all the disinvested businesses are purchased by domestic residents. If some of these purchases come from foreign residents, the resulting net capital inflow would have some favourable effect on the external borrowing and external debt as well. See Ahmad $(1996,1998)$. 
The above policies are designed to reduce the pressure on internal and external borrowing. For further relief, it is also essential that the rate of private savings and productivity rise. For this purpose it is essential to promote stability, efficiency and confidence in the economy. The reduction in borrowing pressure and the increasing role of private sector as implied by the above policies can partially serve the purpose. However, it is also necessary to sustain a better GDP growth rate in the long run. However, since external borrowings are highly sensitive to the growth target and the economy is likely to remain under strict financial constraints, the growth objective is postponed and the GDP growth rate is increased only gradually.

When the GDP growth rate is increased, both the public and private sectors would have to invest more according to the previously given shares of the two sectors. Therefore, both the public and private sector's balances would deteriorate. The required increase in private investment can be realised only when the domestic capital market is relieved of government borrowing. Therefore, in spite of an increase in the budget deficit, net internal borrowing must decrease. Thus the government has to increase external borrowing not only to finance additional investment in public sector but also to divert borrowing from internal to external sources. ${ }^{6}$

To reduce uncertainty and produce stability in the economy, it is suggested that inflation and devaluation of rupee be controlled by a consistent decrease in the growth rate of money supply. These policies would affect directly the internal and external balances to the extent that some of the stock variables are indexed for inflation (external debt and foreign direct capital) while the inflationary factor is included in the interest payments on some other stocks (internal debt and foreign equity capital). Furthermore the results show that apart from the increase in internal borrowing to replace deficit financing by monetary expansion, the direct effects of this policy are relatively small. The increase in internal borrowing is, however, expected to be more than offset by the sale of public assets. It is expected that the anti-inflationary measure would raise real interest rates on domestic saving instruments and coupled with the other measures discussed above, better prospects for gainful investment would promote private savings. This in turn will further improve external balance and relieve the pressure for external borrowing.

Finally, most of the above policies are likely to promote efficiency and productivity in the economy. It is further suggested for the sake of optimal resource allocation that resources are directed towards those sectors where the marginal productivity of investment is relatively better. Thus we assume that capital-output ratio declines gradually from 4 to 3.5. This improvement in productivity improves internal as well as external balances. However internal borrowing would rise to absorb the surplus generated in the private sector.

${ }^{6}$ In other words, since domestic savings are already fully used for investment, the additional investment required to finance an increase in the GDP growth rate has to be funded by external borrowing, irrespective of the shares of the additional investment undertaken in the public and private sectors. 
The effects of the above policy mix on various indicators of resource gap are presented in Tables 6 and 7. The results in Table 6 show that the policy mix has favourable effects on all accounts. The primary budget deficit is expected to decline sharply and from the year 2010-11 onwards the deficit turns into surplus. The increase in the private sector's primary deficit results mainly from increase in taxation and private investment expenditure and the GDP growth rate as required by the policy mix, though these effects are partially offset by the reduced capital output ratio. The primary external deficit also shows a remarkable improvement and it declines by almost 3 percent per annum as against the expected 18 percent increase in the absence of any policy. The current account external and budget deficits also show substantial improvements, though the expected reduction in the former is significantly more than the reduction in the latter. The current account budget deficit is expected to become almost stable.

The improved current account balances in turn translate into decrease in expected borrowings. The net external borrowing is expected to become negative by the year 2016-17 while the gross external borrowing will decrease by 8 percent per annum. The net internal borrowing would, on the other hand, continue to rise, though at a reduced rate. The substantial decrease in external borrowing despite a much smaller improvement in current account external deficit can be explained by the stability of exchange rate resulting from the reduction in the growth rate of money. On the other hand, internal borrowing is expected to increase, though at a lower rate than expected without the policy mix, despite a stable current account budget deficit. This is mainly because, given the net external borrowing, with a decrease in the growth rate of base money, government would have to replace monetary borrowing by direct internal borrowing.

Finally, the internal and external debt positions are also expected to improve significantly after the implementation of the policy. The improvement in external debt position is expected to be more prominent because with the stability produced in the exchange rate, the existing external debt would not grow as fast due to depreciating rupee as was expected in the light of present inflation rate.

Table 7 shows the time profiles of the expected indicators of resource deficits after the implementation of the policy mix. We observe that, except for the private sector's primary deficit, all the indicators show declining trends. For example the current account deficit is expected to remain stable at about 6 percent of GDP while the current account budget deficit would decline to below 5 percent from the year 2003-04 onwards and by the year 2019-20 it will decline to about 1 percent of GDP. The internal and gross external borrowings as percentages of the GDP will decline steadily. The net internal borrowing will also decline, though towards the end of simulation period, it will show a rising trend. 
Table 6 
Table 7 
The internal and external debts as percentages of the GDP would decline to about 20 percent of the GDP as against the expected figures of 69 percent and 33 percent respectively in the absence of the policy mix.

Before closing this section, it is to be noted that the above time paths of resource deficits have been derived from simulation exercises and cannot be taken as the 'estimated' time profiles. In other words, the results are relevant in qualitative, rather than quantitative, sense.

\section{SUMMARY AND CONCLUSION}

This paper has been an attempt to study the nature of present debt crisis in Pakistan with the help of a stock-flow consistent three-gap simulation model. The paper shows that if the interest/rental rates on debt and foreign capital, growth rates of real GDP, foreign capital, foreign exchange reserves, money supply, price level and exchange rate, and the parameters characterising national saving rate and productivity remain unchanged then the debt crisis in Pakistan will worsen. In particular, the current account as well as primary budget and external deficits, internal and external borrowings and public debt will grow to unmanageable magnitudes.

The study considers the effectiveness of various policy instruments in controlling the size of public debt. Keeping in view that a single policy instrument is unlikely to produce desirable results on all accounts, the paper recommends a policy mix that is designed to have balanced effects on all the key indicators of resource deficiency. The policy mix is based on a number of measures including an increase in tax rate, a cut is government consumption expenditure, privatisation, increase in the growth rates of GDP and foreign exchange reserves and a decrease in the growth rate of monetary base. It is assumed that the resulting improvements in the budget and external balances, reduced inflation rate, stability in exchange rate and the encouragement of the private sector, the private savings and productivity will also rise, which further improve the position of resource balances. The policy mix is shown to result in significant favourable effects on many accounts in the long run, especially in terms of a reduced need for internal and external borrowing, better growth performance, economic stability and a reduced risk of default.

Although the study is based on simulation experiments, it provides useful insights in the complex nature of the current debt problem in Pakistan. In particular, we learn that external and internal debt positions should be studied in the context of overall macroeconomic picture. A meaningful solution to the problem lies in addressing simultaneously the core issues of poor saving performance, low productivity, unchecked monetary expansion, unrealistically large public sector and sluggish economic growth. 


\section{REFERENCES}

Ahamd, E. (1996) Capital Inflows and National Debt. The Pakistan Development Review 35: 4 943-960.

Ahamd, E. (1997) Dynamics of Foreign and Domestic Borrowings and Debts. Journal of Economic Cooperation 18:3 71-113.

Ahmad, E. (1998) Retiring Public Debt through Privatisation. Unpublished paper.

Ahmad, E., and M. Idress (1998) The Time Profile of Cost Structure in Pakistan's Manufacturing Sector. Unpublished.

Ahmad, E., and S. Paul (1998) Foreign Investment and the Neo-classical Growth Model. Chapter 6, p. 90-100. In S. Paul (ed) Trade and Growth: New Theory and the Australian Experience. Allen \& Unwin, Sydney. Forthcoming.

Ali, N., E. Ahmad, and R. Butt (1997) Dependency Burden and Savings Rates in Pakistan-A New Strategic Study. Pakistan Economic and Social Review 25:2 95130.

Burney, N. (1988) Determinants of Debt Problem in Pakistan and its Debt Servicing Capacity. The Pakistan Development Review 27: 4 805-816.

Chaudhary, M. A. (1988) International Debt and Foreign Dependency: Policy Options for Pakistan. The Pakistan Development Review 27: 4 829-836.

Cohen, D. (1988) The Management of the Developing Countries' Debt: Guidelines and Applications to Brazil. The World Bank Economic Review 2:1.

Crouch, R. L. (1973) Economic Development, Foreign Aid, and Neo-classical Growth. Journal of Development Studies 9: 353-364.

Naqvi, S. N. H. (1970) The Foreign Capital Requirements and External Indebtedness of a Developing Country: A Case Study of Pakistan. In E. A. G. Robinson (ed) Economic Development in South Asia. London: M. Stockton, 504-524.

Rahman, M. A. (1967) The Pakistan's Perspective Plan and the Objective of Elimination of Dependence on Foreign Assistance. The Pakistan Development Review 7:3 412-415.

Tanzi, V., M. I. Blejer, and M. O. Teijeiro (1988) The Effects of Inflation on the Measurement of Fiscal Deficits. In M. I. Blejer and C. Ke-Young (eds) Measurement of Fiscal Impact: Methodological Issues. International Monetary Fund, Washington, D. C. (Occasional Paper 59.) 